\title{
The Importance of Maritime Law in Seafarer Training Pursuant to Amendments to the STCW Convention
}

\section{Ranka Petrinovića ${ }^{a}$ Nikola Mandića, Ena Siriščevićb}

This paper explores the role of maritime law in seafarer training pursuant to amendments to the STCW Convention of 2010. The basic intention of the STCW Convention adopted in 1978 was to harmonize national regulations, seafarer training and training programs, as well as the conditions and manner of seafarer certification to raise general qualification levels of seagoing vessel crews. The STCW Convention is occasionally amended to allow legislation to take into account and stay abreast of the changing technical standards in shipping. The latest amendments to the STCW Convention were adopted at the Manila Diplomatic Conference in 2010, and entered into force and effect on 1 January 2012. Member states are required to complete the procedure of gradual implementation of the new provisions by 31 December 2016, with all seafarers being required to obtain certificates issued in accordance with the amended regulations by 1 January 2017. Although ship navigation during sailing has been significantly facilitated by the development of technics and technology, seafarers are now required to be well-versed in an increasing number of maritime law regulations and procedures promoting the safety of life and property at sea and the protection of the marine environment, while simultaneously ensuring unobstructed exploitation of ships. The latest amendments to the STCW Convention in this sense, in Model Course 7.01., impose additional seafarer training requirements, inter alia, broadening the scope of mandatory contents to be covered by maritime law courses required for the obtainment of the professional title of ship officer. The paper pays especially close attention to the newly adopted amendments and the conformity of national legislation proscribing seafarer training standards. However, it is exactly in the domain of seafarer training in maritime law that harmonization may be said to be incomplete.

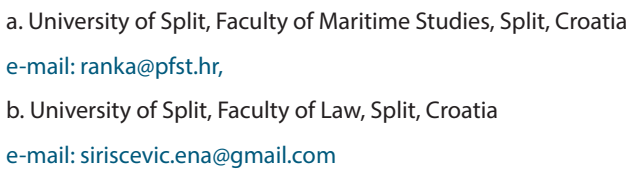

\author{
KEY WORDS \\ $\sim$ Maritime law \\ $\sim$ Seafarer training \\ $\sim$ STCW Convention \\ $\sim$ Model Course 7.01 . \\ $\sim$ Ordinance on Vocations and Certificates of Competencies for \\ Seafarers
}

\section{INTRODUCTION}

A person responsible for the safety of the vessel, persons and cargo must, by the nature of things, be present on board of every ship. This person must, given his functions, have the authority to issue commands. Such knowledge and skills are vested in the person of the Master. The Master is personally responsible for the safety, i.e. seaworthiness of the ship. The Master, i.e. Deck Officer on duty controlling ship operation must take any measures necessary to ensure the safety of the ship and the safety of navigation. The Master is likewise required to personally navigate the ship when required to ensure its safety. The Master and Deck Officers must execute their work tasks on the ship in keeping with their duties proscribed by the law, other regulations and rules of navigation, without jeopardizing the safety of life, property and the marine environment. However, these are not the only obligations of the Master. Apart from ensuring the safety of the ship and navigation, the Master also acts as the legal representative of the ship owner, authorized to conduct certain legal transactions on the behalf and for the account of the ship owner.

An increasing number of duties of the Master and Deck Officer in modern marine navigation concern the execution of special procedures proscribed by international conventions and national legislation. Apart from discharging his nautical and commercial duties, the Master is also required to perform tasks relating to certain legal procedures. It is therefore important for Masters to acquire, in the course of their training and prior to 
earning their professional title at management level, inter alia, the legal know-how necessary for the overall ship management process, and especially required to ensure the safety of navigation and the protection of the marine environment. By knowing the norms of maritime law the Master secures his, and therefore his ship owner's position.

Inter alia, the International Convention on Standards of Training, Certification and Watchkeeping for Seafarers (the STCW Convention) proscribes seafarer training requirements. Model Course 7.01, adopted on the basis of the STCW Convention, proscribes contents every trainee is required to adopt in order to take the Master or Deck Officer exam. Knowledge of maritime law is a precondition for the obtainment of the highest professional titles at management level.

The paper analyses the relevance of maritime law in seafarer training, with special emphasis on the novelties introduced into Model Course 7.01., supplementing and expanding the knowledge base required to be adopted to earn professional titles at the management level. This primarily pertains to: United Nations Convention on the Law of the Sea, Maritime Labour Convention, salvage, marine insurance, stowaways, shipping agents and agencies, places of refuge, Master - pilot relationship, the International Convention for the Control and Management of Ships Ballast Water and Sediments, port state supervision and national legislation.

\section{INTERNATIONAL CONVENTION ON STANDARDS OF TRAINING, CERTIFICATION AND WATCHKEEPING FOR SEAFARERS (STCW CONVENTION)}

The STCW Convention was adopted on 7 July 1978 and entered into force on 28 April 1984. ${ }^{1}$ Amendments to the Convention were adopted at the 1995 Diplomatic Conference in London, which entered into force on 1 February 1997 and the 2010 Diplomatic Conference in Manila, which entered into force on 1 January 2012. It was the first convention to proscribe basic requirements for the training, certification and watchkeeping for seafarers at the international level. The STCW Convention sets minimum requirements binding on signatory countries and harmonizes national regulations on the training of seafarers to raise the general qualification level of seagoing vessel crews, which is simultaneously the purpose of the adoption of the STCW Convention, given that the so called human factor is the most frequent cause of maritime accidents. The STCW Convention is rightly considered one of the most important international instruments for the safety of navigation and the protection of the marine environment ever adopted under the auspices of the International Maritime Organization (IMO).

1. According to the data of the International Maritime Organization available on 21 January 2016, the STCW Convention was ratified by 160 states, representing $98,55 \%$ of the global merchant navy gross tonnage.
The STCW Convention is organized under the following eight chapters:

Chapter I: General provisions,

Chapter II: Master and Deck Officers,

Chapter III: Engine room department,

Chapter IV: Radio communications and the radio department,

Chapter V: Special training requirements for the crews of particular vessel types,

Chapter VI: Emergencies, safety-at-work, healthcare and survival, Chapter VII: Alternative certificates,

Chapter VIII: Watchkeeping.

A number of supporting resolutions were also passed at the STCW Convention. The 23 resolutions are conceived as recommendations rather than having a compulsory character and regulate the issues from the Convention in more detail. Resolutions especially regulate specialized know-how required for certain ship types and parts and the performance of work tasks on board.

Amendments to the STCW Convention adopted at the 1995 Diplomatic Conference, together with amendments to the Annex to the Convention and the adoption of the so called STCW Ordinance significantly altered the Convention, making its provisions stricter, more precise and binding. The STCW Convention and the STCW Ordinance constitute a unique whole in which the rules stipulated in the Annex to the Convention are elaborated in Chapters of the Ordinance. The Ordinance consists of two parts - Part A is compulsory in nature ${ }^{2}$, while Part B has the character of a recommendation.

The STCW Convention differentiates between three levels of responsibility - management, operational and support. The management level of responsibility applies to: (a) the Master, Chief Officer, Chief Engineer or Second Engineer Officer on a seagoing vessel or (b) i. e. to the assumption of overall responsibility for the proper performance of all or particular activities on a seagoing vessel. The operational level of responsibility applies to: (a) officers responsible for navigational watchkeeping or engine room watchkeeping or engineers allocated to the engine room which is occasionally left unmanned and radio operators on board seagoing vessels, i. e. (b) immediate responsibility for a particular activity. The support level of responsibility concerns assistance with navigational or engine room watch, watchkeeping in ports or cargo handling or transshipment operations on board a seagoing vessel.

The STCW Convention pays special attention to quality standard assurance at all levels. Every member state is required

2. Part A of the Ordinance contains mandatory provisions especially referred to in the Annex to the Convention, establishing in detail minimum standards member states (signatories) are required to implement for the Convention to have full and comprehensive effect. It also contains standards of competencies trainees must prove to possess to be certified or for their certificate of competency to be renewed pursuant to Convention provisions. 
to ensure the identification of clear-cut education and training objectives and the standard of competencies to be realized, while simultaneously proscribing the levels of know-how, comprehension and skills suitable for testing and grading in compliance with the provisions of the Convention.

The signatories of the STCW Convention are required to submit to the IMO detailed information on all elements relevant for Convention implementation. This obligation includes having to notify the IMO of training programs, manner of examination, certification, system for monitoring the actual status of issued certificates, as well as of the staffing and the level of technical equipment at the disposal of authorized seafarer training and certification organizations and institutions.

The Republic of Croatia is required to ensure the systematic application of the provisions of the STCW Convention by establishing working cooperation between the competent state bodies, scientific and educational institutions, in order to raise the safety of navigation standards and enable Croatian seafarers to continue their successful navigation of the world's seas.

\section{MODEL COURSE 7.01 (MASTER AND CHIEF OFFICER)}

The Model Course program evolved from the numerous proposals of International Maritime Committee member state governments, following the adoption of the STCW Convention. Due to their contribution, the IMO published a number of courses assisting with the implementation of the STCW Convention, to facilitate access to the knowledge and skills rendered necessary by the increasingly sophisticated maritime technologies. The courses are flexible in application and may be used to assist maritime training institutions and their teaching staff with the introduction and organization of new training courses and to enhance, update or supplement existing training material. Every model course consists of the framework (scope, goal, entry level standards and other information on the course), course plan, detailed syllabus (including learning outcomes intended to be achieved after course completion), guidelines for educators and a grading summary.

Model Course 7.01. builds up the knowledge and skills of Deck Officers, improving their ability to ensure safety-at-work on board a ship and the protection of the marine environment. The content of Model Course 7.01. was revised following the 2010 amendments to the STCW Convention.

The 2014 version of Model Course 7.01., section 3.2. Monitoring and Control of Compliance with Legislative Requirements, proscribes mandatory content from the domain of maritime law. The nine sub-sections regulate:

1.1 Certificates and other documents required to be carried on-board ships by international conventions,
1.2 Responsibilities under the relevant requirements of the International Convention on Load Lines,

1.3 Responsibilities under the relevant requirements of the International Convention on Safety of Life at Sea (SOLAS),

1.4 Responsibilities under the International Convention for the Prevention of Pollution from Ships (MARPOL),

1.5 Maritime declarations of health and the requirements of the International Health Regulations (incoming documents and procedures, plague, cholera, yellow fever, documents),

1.6 Responsibilities proscribed by other international maritime law embodied in international agreements and conventions affecting the role of management level Deck Officers:

1.6.1 Convention on Facilitation of International Maritime Traffic (FAL),

1.6.2 United Nations Convention on the Law of the Sea (UNCLOS),

1.6.3 Maritime Labour Convention (MLC),

1.6.4 Collision,

1.6.5 Rescue and salvage,

1.6.6 Convention on Limitation of Liability for Maritime Claims,

1.6.7 Classification of companies,

1.6.8 Cargo (Hague-Visby Rules, Accident Investigation Ordinance, Charter parties, the Hamburg Rules),

1.6.9 Common average and marine insurance,

1.6.10 Marine insurance and liability (protest statement and lodging, protest letter),

1.6.11 Stowaways

1.6.12 Shipping agents and agencies,

1.6.13 Procedures in places of refuge,

1.6.14 Master-pilot relationship,

1.7 Responsibilities under international instruments affecting the safety of the ship, passengers, crew and cargo,

1.8 Methods and aids to prevent pollution of the marine environment by ships,

1.9 National legislation implementing international agreements and conventions.

In comparison with the previous version, new Model Course 7.01. introduces certain novelties in the domain of maritime law. The key and most important novelty is that the minimum number of hours dedicated to maritime law increased from 36 to 54. The new content required to be taught to and adopted by seafarers deals with: UNCLOS, MLC, salvage, marine insurance and liability, stowaways, shipping agents and agencies, places of refuge, Master/pilot relationship and national legislation. The above new contents and their relevance for the Master of a ship in international navigation will be examined and explained in further text. 


\subsection{United Nations Convention on the Law of the Sea (UNCLOS)}

International relations relating to the sea and maritime activity must be regulated by international law, which, owing to its long history, developed as common law. In the $20^{\text {th }} \mathrm{ct}$., attempts were made to codify the international law of the sea by the adoption of international conventions, which proved to be an exceptionally difficult task due to the sensitivity of the subject matter. Partial success was achieved in Geneva in 1958, when four international conventions were adopted: Convention on the Territorial Sea and the Contiguous Zone, Convention on the High Seas, Convention on Fishing and Conservation of the Living Resources of the High Seas and Convention on the Continental Shelf. Only a couple of years after entry into force of the Geneva conventions, the discussion on new regulation of maritime legal relations commenced, since the Geneva conventions were only relatively successful. For example, they failed to set the width of the territorial sea. The Third United Nations Convention on the Law of the Sea convened in 1973. After lengthy discussion and a number of sessions, the UNCLOS was ceremoniously signed in Montego Bay (Jamaica), on 10 December 1982. The convention, which entered into force on 16 November 1994, is considered one of the most important multilateral agreements in the international community, second only to the United Nations Charter.

The UNCLOS is a comprehensive codification document constituting the greater part of the international legal order. It balances out, on the one hand, the need to maintain the freedom of navigation (and other freedoms of the high seas) and, on the other, the need to meet the interests of coastal states in sufficiently large expanses of the sea in front of their shores (expansion of the epicontinental belt, establishment of economic belt and the institute of archipelagic waters of archipelagic states).

Seafarers are constantly in touch with the institutes of the international law of the sea. Their navigation most frequently begins in the internal waters of their own or another state, continues through the territorial waters, the economic belt and the high seas, only to end in internal waters (ports) again. They also have to deal with the issue of the freedom of the high seas, and especially the freedom of navigation guaranteed not only at high seas, but also in areas over which coastal states have sovereignty.

The UNCLOS envisages eight distinct legal regimes, each applying to a different part of the sea, the seabed and the underground, as well as the aerial space above the sea. The determination of the legal regime to be applied depends on the rights to certain uses of the sea like: navigation, fishing, pipeline and cable laying, aircraft overflight, scientific research of the sea and construction of artificial islands and devices within the confines of the respective space, which uses constitute exclusive rights of coastal states or freedoms (rights) benefiting all states, coastal and landlocked alike, as well as physical and legal persons worldwide. At high seas, all the above uses are freedoms belonging to all states. By contrast, in internal waters, archipelagic waters and even territorial sea, the majority of such uses are interpreted as exclusive coastal state rights. Apart from uses of the sea, owing to the increasing risk of pollution, coastal states are granted additional important jurisdictions relating to the protection and preservation of the marine environment. This issue is regulated by a separate part of the XII. Convention titled Protection and Preservation of the Marine Environment, containing norms of crucial importance not only for coastal, but for landlocked states and the future and fate of the humankind in general.

The UNCLOS consists of 17 parts covering all institutes of the international law of the sea like: the territorial sea and the contiguous zone, straits used in international navigation, archipelagic states, exclusive economic belt, epicontinental belt, high seas, island regime, closed or semi-closed seas, right of access of landlocked states to and from the sea and freedom of transit, protection and preservation of the marine environment, the Zone, scientific research of the sea, development and transfer of maritime technologies.

\subsection{Maritime Labour Convention (MLC)}

The MLC was adopted at the $94^{\text {th }}$ session of the International Labour Organization (ILO) held in Geneva in February 2006, as a tripartite agreement between the governments, seafarer unions and ship owner's representatives. ${ }^{3}$ Its intention is to further improve the status, i.e. working, living and social rights of seafarers, of whom there are 1,5 million worldwide and approx. 27 thousand in Croatia alone. Given its exceptional importance to seafarers, the MLC came to be known as the fourth pillar of quality shipping, supplementing the most important instruments of the IMO: SOLAS, MARPOL and STCW conventions. It is also known as the Maritime Labour Charter.

The MLC entered into force in August 2013, a year after being ratified by 30 ILO member states accounting for a total of $33 \%$ of the world's tonnage. It has been ratified by 70 states accounting for $87 \%$ of the world's total gross tonnage ${ }^{4}$, including most of EU member states.

The MLC consolidates and modernizes standards set forth in 68 existing conventions and recommendations adopted by the ILO since 1920. Without imposing significantly different requirements, but still proscribing the obligations of the flag states and the obligation of port state inspection, the MLC

3. The delegates of 104 ILO member states participated at the Conference, including the delegation of the Republic of Croatia.

4. Data available on 26 January 2016. 
introduced by the Convention of 1989 are that salvors are encouraged to protect and prevent the pollution of the marine environment.

While the salvage of human life is mandatory, the salvage of property is not. The salvage of property may be spontaneous or contracted. Spontaneous salvage is the voluntary salvage of property effected without a pre-concluded salvage contract, while contracted salvage is effected on the basis of a contract between the salvor and the owner of property in peril. Salvage contract is an informal legal transaction since for it to be considered concluded and valid it need not be concluded in any pre-defined form. Regardless of the freedom of contract conclusion, salvage contracts are, as a rule, concluded in written form. English Lloyd's Standard Form of Salvage Agreement (abbreviated to Lloyd's Open Form - LOF) is most frequently used for international contracts. LOF 1995 and LOF 2000 are currently in use, with the latest revision made in 2011.

Regardless of whether salvage is spontaneous or contracted, the salvor is entitled to a reward for any successfully salvaged property. Salvage contract may stipulate the amount of the salvage reward in advance or the manner of its subsequent establishment, although reward is seldom contracted in advance in contemporary practice. The latest versions of the LOF do not even contain the field for entry of reward amount, but define the criteria for its establishment instead.

Salvage reward may not exceed the value of the salvaged property determined at the place and time of salvage completion pursuant to the Salvage Convention (Article 13.) and the LOF. The following criteria are used to determine the amount of the salvage reward: value of the salvaged vessel and other property, skill and effort invested by the salvor to prevent or minimize environmental damage, level of success, nature and level of danger, skill and effort of the salvor invested to save human lives, the vessel and other property, time spent, expenses and losses suffered by the salvor, liability risk and other risks salvors or their equipment were exposed to, the speed of service provision, availability and utilization of ships and other equipment during the salvage operation, as well as the level of readiness, efficiency and value of the salvor's equipment. The order in which the criteria for the determination of the amount of the salvage reward were listed is irrelevant for the application thereof.

The Salvage Convention of 1989 introduced a special reward to encourage the salvors to prevent the pollution of the marine environment during salvage operations. A salvor is entitled to the special reward only if he participated in pollution prevention, but failed to realize the right to the salvage reward. These two preconditions (a vessel jeopardizing the marine environment and the salvor who did not realize the right to the reward) for the realization of the right to the special reward are required to be met cumulatively. When determining the amount of the special reward, the Salvage Convention of 1989 distinguishes between two situations. If a salvage operation failed to prevent or minimize environmental damage, a salvor who did not realize the salvage reward is entitled to the special reward, but only in the amount equal to the actual salvage expenses. If, on the other hand, the salvage operation manages to successfully prevent or minimize environmental damage, the competent court may increase the actual expenses of the salvor by $30 \%$ and in some cases by the maximum $100 \%$ when establishing the amount of the special reward. If a salvor realized the right to the salvage reward due to having fully or partially salvaged the vessel and cargo while preventing pollution, the salvor is not entitled to the special reward.

Contractual form LOF 2000 is the tenth version of the form since its establishment. In practice, the relative unsuccessfulness of the convention solution to encourage the salvors to protect the marine environment by proscribing the special compensation, induced professional salvors and P\&l Clubs (as insurers against liability disbursing the special compensation) to conceive and offer to business practice a special tariff system for the determination of the amount of the reward, called SCOPIC (Special Compensation of Protecting and Indemnity Clause). This clause was added to LOF 2000 by having the contracting of the SCOPIC listed as an option which may but is not required to be used with the LOF. The salvors' security in reward realization is greater with the SCOPIC than with the special compensation, and P\&I Clubs have the opportunity to supervise salvage operations.

The clause proscribes the establishment of the compensation in accordance with the pre-determined and contracted criteria, providing that the contracting of the SCOPIC excludes the application of Article 14. (special reward) of the Salvage Convention. Salvors may invoke SCOPIC in any stage of the salvage operation, providing certain requirements are met, regardless of whether the marine environment is endangered or not.

Regardless of the contracting of the SCOPIC, the salvage reward is determined in keeping with the criteria defined in Article 13. of the Salvage Convention, with the compensation under SCOPIC being disbursed only if it exceeds the salvage reward. If the compensation is lower, the salvage reward is reduced by $25 \%$ of the difference between the salvage reward and the compensation calculated in keeping with the SCOPIC. A salvor may stop providing salvage services if his expenses exceed the value of the salvageable property and any amounts he is entitled to under the SCOPIC.

As discernible from its characteristics, the SCOPIC enabled the salvors to collect the salvage reward faster and safer, but failed to sufficiently contribute to the protection of the marine environment, leaving the public-legal issues stemming from the Salvage Convention unresolved. 


\subsection{Marine Insurance}

As a rule, ships and their cargo are insured. These interests and the liability of the ship owner are covered by marine insurance. Marine insurance is provided by insurance companies doing business on the principle of premium-based policies and mutual insurance companies - P\&I Clubs (charging contributions). Marine insurance rests on the principle of voluntarism. The law exceptionally proscribes cases for which insurance coverage is mandatory, e.g. some forms of third party liability insurance (ship or yacht owner third party liability insurance, tanker owner pollution liability insurance, nuclear vessel operator's liability insurance, ship owner's motor fuel pollution liability insurance, ship owner's wreck removal liability).

Marine insurance is contract-based. Masters are required to be familiar with both the content of the ship insurance contract and the content of the liability insurance contract provided by P\&l Clubs.

Marine insurance contract is an informal contractual transaction. Therefore, for it to be considered concluded and valid it need not be concluded in any pre-set form. The contract is valid if the contracting parties agree on the key elements, namely on: the insured object, insured risk, insurance premium or contribution and insurance compensation. Still, it is an established years-long practice to issue an insurance document (written cover note) certifying that an insurance contract was concluded, for legal security purposes. Insurance policy, issued by the insurer to the policyholder upon contract conclusion or thereafter, is the most important document proving the conclusion of an insurance contract.

The marine policy is the most frequently used insurance policy in marine insurance. Policy insuring goods is called cargo policy and policy providing coverage for vessels is known as the hull and machinery policy. The so called new marine policy form, in circulation since 1983, is currently in use.

Insured loss means the loss of or damage to an insured object, as well as any other covered loss or expense caused by an insured risk. The occurrence of an insured risk may result in the total or partial loss of or damage to an insured object and give rise to a variety of expenses and obligations of the insured towards third parties. Premium policy does not cover (contractual or extra-contractual) liability of the insured for damage inflicted on third parties. Liability insurance requires special contractual arrangements. It is common for ship owners to insure their liability with special organizations, the so called P\&I Clubs.

Excluded losses are a special loss category in marine insurance, which may be proscribed and contracted. Losses directly or indirectly arising from the willful misconduct of the insured may not be insured even by direct contractual provisions. The second group of excluded losses are losses insurable by special contractual provisions (e.g. war and political risks).
Contracted conditions of insurance constitute an integral part of the contract. Institute clauses are the best known ship insurance conditions. All risks are divided into marine, war and political risks. There are special conditions of insurance against marine, and special conditions of insurance against war and political risks. The conditions of insurance against marine risks expressly exclude war and political risks from coverage.

Ship insurance institute clauses are sets of clauses regulating the most important issues from the contractual relationship. Institute time clauses - hulls are the basic conditions of ship insurance. Institute clauses published in 1983 and 1995, including the latest international hull clauses, are used exclusively in conjunction with the new marine policy form - form MAR). There are several institute clauses regulating insurance against marine risks mutually distinguishable by the scope of coverage. Institute time clauses - hulls (insurance of ships against particular weather) and institute voyage clauses - hulls (ship voyage insurance) provide the broadest coverage.

Ship insurance covers the hull, machinery, devices and equipment, regular fuel, lubricant and other ship's material stocks, as well as food and beverage stocks for the crew's use. Institute time clauses - hulls (full coverage) deal with insured risks in two clauses: perils clause and pollution clause. It is common for the institute clauses to contain special ship class and navigating limit clauses. Ship insurance contracts require ships to be classified, while the classification clause of the 1995 institute clauses requires the insured to obtain the class from the classification society approved by the insurer. Ship insurance automatically ceases to be valid in case of class change, suspension, cessation, cancellation or expiry, as well as in the event of substitution of the class allocated by a classification society for the class of another classification society.

Limited term ship insurance regularly contractually limits the area of navigation. Navigating limits are contracted by using geographical criteria to define areas in which a ship is allowed to navigate (institute warranty clauses).

Since standard ship insurance does not cover the majority of possible aspects of ship owner's liability, special mutual ship insurance organizations - protection and indemnity associations (P\&IClubs) were established. P\&IClubs are insurance organizations joined by ship owners to insure against risks uninsurable with insurers doing business on the principle of premium policies. Those are primarily different aspects of liability, as well as other expenses ship owners are exposed to. P\&I Clubs issue a document similar to insurance policy for each joining vessel, known as the Certificate of Entry. One of the major differences between premium and mutual insurance is that no fixed premium, i.e. contribution is paid for P\&I coverage. The majority of P\&I Clubs were founded and do business in England. They associated into International Group of P\&I Clubs. Contemporary P\&I Clubs cover the liability of their members for: bodily injury, illness or loss of life 
of crew members, dock workers, passengers and other persons; loss of personal items; saving human life; collision liability (if not covered by premium insurance); pollution liability; contractual liability; wreck obligations; cargo liability; certain expenses and legal expenses.

Familiarity with the structure of $P \& I$ insurance and the relationship of that insurance with hull and machinery insurance (premium insurance) is of great importance for Masters. Their duties in concrete situations depend on the content of these insurances.

\subsection{Stowaways}

A stowaway is a person who is on board a ship for transportation purposes, who did not conclude a transportation contract with the shipper or his representative and is secreted on the ship without his consent. The position of stowaways is not regulated by any international convention (the International Convention on Stowaways was adopted in Brussels in 1957, but never entered into force). National legislations have different solutions for this issue, causing significant difficulty in practice.

The shipper and the Master are required to cooperate with the port authorities and state administration to the greatest extent possible if any stowaways are detected on board a ship. Stowaways must be treated humanely, giving due consideration to the operational safety of the ship and the well-being of the stowaway. Every effort must be taken to avoid the lingering of stowaways on ships for an indefinite period, for which purpose state administrations should cooperate with the shipper to organize the return of the stowaways to the relevant state (the state of port of first embarkation of the stowaway).

IMO has introduced various guidelines on stowaway matters, the latest being Resolution A.871(20), adopted on 27 November 1997, and its Annex - Guidelines on the Allocation of Responsibilities to seek the Successful Resolution of Stowaway Cases. Special emphasis is placed on the prevention of illegal embarkation and the distribution of duties between the Master, ship owner or operator, port of stowaway disembarkation, port of stowaway embarkation, state which stowaway is a national of, ship flag state and every transit state during repatriation.

\subsection{Shipping Agents and Agencies}

Shipping agent is a special institute in maritime law and economy. The activity of shipping agents is of exceptional importance in contemporary marine transportation and marine transactions not involving shipping agents are almost nonexistent. A shipping agent is a professional without whose services contemporary marine traffic and economic exploitation of seagoing vessels would be unimaginable. The performance of an entire array of tasks during the stay of a ship in a port or relating to marine agency and conclusion of marine contracts is inconceivable without shipping agents. A shipping agent assists the ship owner, i.e. Master in all tasks concerning cargo procurement or ship dispatching, while simultaneously helping cargo owners to find a ship, connecting them with the ship owner or assisting with the conclusion of shipping contracts. Owing to his expert execution of the above transactions, knowledge of the local situation, regulations, language and customs, a shipping agent is best suited to resolve different issues relating to the ship or the cargo it carries, while simultaneously safeguarding the interests of his principal. The development of communication systems enabled the shipping agents to remain in constant contact with their clients and thus expand their services to include the execution of shipping contracts.

A shipping agent may be defined as a legal or physical person performing the jobs of representation, agency and assistance with marine transactions on the behalf and for the account of a principal on the basis of a general or special power of attorney, with the principal in return being required to pay a fee and compensate the shipping agent for any expenses. Jobs of representation means representation during ship arrival and dispatch, representation of the ship owner before port authorities and in relations with other persons. Jobs of agency means mediation with the conclusion of contracts of exploitation of seagoing vessels, mediation with ship purchase, building and overhaul, mediation with the insurance of a maritime undertaking and mediation with crew recruitment. Assistance means providing assistance to the Master, crew members and passengers.

The business activity of marine agency is not regulated by any international convention. The UNCTAD Minimum Standards for Shipping Agents were adopted at the United Nations Conference on Trade and Development on 7 September 1988. The UNCTAD Minimum Standards for Shipping agents lay down the definition of a shipping agent, define the list of tasks, authorities of the shipping agent, shipping agent and shipping agency types, obligations of the agent towards the principal and shipping agent appointment.

Seafarers, especially Masters, are required to have knowledge of the basic principles of shipping agency. Masters are in almost continuous contact with shipping agents to ensure unobstructed navigation, i.e. entry of their ship into port, performance of all ship and cargo manipulations and departure of the ship from port. Some marine transactions are carried out partially by the shipping agent and partially by the Master. In case of dispute, Master has precedence. Master is an employee of the ship owner who is, pursuant to the regulations of the majority of countries, considered to be a legal representative of the ship owner, performing nautical, commercial and publiclegal functions on and for the ship. A shipping agent is a person offering his services to the ship owner on the basis of a shipping 
agency agreement. The Master is therefore considered to be the main, and the shipping agent a lower ranking representative of the ship owner. The Master should also be noted to be an employee of the owner, while the shipping agent is not.

\subsection{Places of Refuge}

Place of refuge is a protected place in the vicinity of the shore in which a ship in need of assistance may, if needed, eliminate possible cause of an accident and minimize the danger the ship would otherwise pose to the safety of navigation and the marine environment. The idea of places of refuge for ships in need of assistance dates back to the late 1980s, when the Salvage Convention was drafted. Maritime accidents of tankers Erika, Castor and Prestige, as well as other accidents, occasioned the adoption of IMO guidelines on places of refuge:

- $\quad$ Resolution A. 949 (23) - Guidelines on places of refuge for ships in need of assistance - is applied when a ship is in need of assistance, but human lives are not in danger.

- Resolution A. 950 (23) - Maritime assistance service recommends coastal states to establish a maritime assistance service.

The first Resolution is applied when a ship is in need of assistance, but human lives are not in danger. When human lives are in danger, the provisions of the SAR Convention apply. Guidelines of Resolution A 949 (23) of the IMO stipulate that when a ship suffers a maritime accident causing its progressive deterioration, the best way to prevent damage or pollution is to remove its cargo or bunker to allow the damage to be repaired. This procedure is best conducted in a place of refuge.

The second Resolution A. 950 (23) recommends all coastal states to establish a maritime assistance service (MAS). The service is primarily intended to receive various reports, advice and notifications proscribed by different IMO instruments; to supervise a ship's condition if the relevant report indicates that an accident could cause the ship to be in need of assistance; to serve as a data collection centre if the condition of the ship is neither worrying nor dangerous, but still requires information exchange between the ship and the coastal state (in case the condition of the endangered ship deteriorates); and to serve as the centre for communication with salvors participating in the salvage of the endangered ship, if the respective coastal state requires all stages of the salvage operation to be supervised.

After the environmental disasters of tankers Erika and Prestige, the European Union adopted Directive 2002/59/EC establishing a vessel traffic monitoring and information system on 27 June 2002 (entered into force in February 2005) requiring member states to devise a detailed plan of action for ships in need of assistance and submit a list of places of refuge allowing easier salvage of ships in need of assistance and a more efficient prevention of pollution of the marine environment.
In 2008, Croatia adopted the Ordinance on Places of Refuge proscribing in detail the procedure of selection and approval of places of refuge for ships in need of assistance, competent bodies and persons responsible for the selection and approval of such places, conditions to be met by places of refuge, manner of use of places of refuge and mandatory insurance, i.e. other financial security for any damage and expenses relating to the sheltering of ships in places of refuge. The Ordinance also establishes the obligation of adoption and prompt maintenance of the plan for sheltering ships in need of assistance, as an essential execution document which, in compliance with Resolution A.949 (23), contains all data required for the selection of places of refuge. The Ordinance does not expressly mention any concrete port or place of refuge, but rather stipulates that such place is to be selected depending on the situation. Data on possible places of refuge have been uploaded into the GIS application, as a decision making support system containing possible places of refuge and other related information.

The plan for sheltering ships in need of assistance, as an essential execution document, contains a variety of data required for successful sheltering of a ship in danger in a place of shelter. The plan elaborates the stages of selection of a place of refuge proscribed by the Ordinance on Places of Refuge (request for approval and allocation of place of refuge, assessment of justifiability of approval of place of refuge, allocation of place of refuge and provision of assistance at place of refuge). The request of the Master of a ship in need of assistance for the approval and allocation of a place of refuge, containing all data necessary for the assessment of the ship's situation, is considered the beginning of the process of allocation of a place of refuge.

\subsection{Master/Pilot Relationship}

Pilotage is the navigation of a vessel by professionals (pilots) giving expert advice to Masters to ensure safe navigation in ports, through straits and other areas within internal waters and territorial sea. Pilots are required to:

- refuse pilotage if a ship's draft is incompatible with sea depth at the place the ship is expected to moor or anchor at, i.e. if safe mooring conditions have not been ensured at the place of mooring, if a ship is not seaworthy, or if it failed to obtain the port authority's approval to enter or leave the port and if the Master of the ship in need of pilotage refuses advice regarding pending pilotage,

- $\quad$ in the course of pilotage give expert navigation advice to the Master, warn him of navigating conditions and indicate applicable local regulations,

- following the completion of pilotage, inform the port authority by radio of pilotage commencement and completion and in some cases, inform the port authority thereof in writing.

Vessel pilotage does not release the Master of the ship using 
pilotage services from the obligation and responsibility for vessel navigation and maneuvering. A pilot, being well-acquainted with the local maritime-nautical situation, merely performs the function of advisor to the Master. The Master always has the final say on any maneuver to be taken and retains full nautical control of the ship. In principle, the ship, i.e. the ship owner is always liable for any damage caused to third parties through the fault of the pilot, regardless of whether pilotage was compulsory or voluntary.

In 2003 the IMO adopted Resolution A.960 (23) regulating training, certification and operational procedures for maritime pilots. Appendix 1 to the Resolution titled: Recommendations regulating training and certification of maritime pilots, with the exception of deep sea pilots, proscribes: the field of application, competent body for pilotage, pilotage certificate or license, medical fitness, training and certification or licensing standards, syllabus for pilot certification or licensing. Appendix 2 to the Resolution titled: Recommendations for the operational procedures of maritime pilots, with the exception of deep sea pilots, proscribes: the duties of the Master, Deck Officer and pilot, pilot embarkation point, procedure for requesting a pilot, information exchange between the Master and the pilot, language of communication, reporting on incidents and accidents, refusing pilotage and competence for the execution of this function.

\subsection{International Convention for the Control and Management of Ships Ballast Water and Sediments (BWC)}

Ballast waters are one of the most dangerous polluters in existence, frequently polluting the marine environment. Ballast water is water containing substances, loaded to control the ship's trim, incline, draft, stability and stress. The resolution of this issue at the international level was given special consideration over a decade ago.

The BWC was adopted on 13 February 2004, and will enter into force twelve months after being ratified by 30 states accounting for $35 \%$ of the world fleet ${ }^{5}$.

The Convention aims to prevent, reduce and finally eliminate the spread of harmful aquatic organisms and pathogens by managing and controlling ballast waters and sediments in keeping with the principles of international law. Member states are required to ensure that ballast waters do not damage the environment, human health, property and resources of their own or any other state. The Convention regulates the issue of ballast water reception, research and supervision matters and proscribes investigation, certification, inspection and technical

5. According to the data of the International Maritime Organization available on 11 February 2016. The BWC has been ratified by 47 states accounting for $34,35 \%$ of the world fleet. assistance procedures. Apart from general provisions, Annexes to the Convention also stipulate the manner of management and supervision of ship compliance, additional measures and ballast water management standards, especially ballast water replacement standards. They also deal with the prototypes of required technologies and manner of standard modification.

To the extent allowed by the safety of navigation and protection of the marine environment requirements, Masters are required to avoid or limit ballast water loading in areas known to be inhabited by harmful microorganisms, known to serve as factory discharges, in which underwater trenching is performed, characterized by an exceptionally large tidal range, high level of murkiness due to the operation of ship propellers (shallow ports, estuaries, anchorage), fish spawning and current convergence. With regard to ballast water management measures, the crew are required to be familiar with their ship-specific duties and, depending on their function, with the ship's ballast water management plan.

\subsection{Port State Supervision}

Port state may inspect any foreign ship entering its port. In this respect, port state inspection and supervision should be noted to be more efficient if conducted systematically, consistently and in a coordinated manner. To that end, within the framework of the jurisdiction provisions of the MARPOL Convention and the UNCLOS, western European countries adopted a Memorandum of Understanding (the Paris Memorandum) in Paris, in 1982. The Memorandum was adopted by 14 European countries, subsequently joined by additional 13, totaling to 27 member states. $^{6}$

The Paris Memorandum is a document of exceptional importance, aiming to achieve the uniformity and coordinate the inspection procedures in the ports of member states. There are currently eight different memorandums of understanding on port state supervision in existence worldwide. Signatory countries are required to organize an efficient and networked foreign ship control system to comply with the safety at sea and protection of the marine environment standards and improve the working and living conditions of the crew. Signatories are required to seek each other's advice, cooperate and exchange information.

Rather than setting up new standards, the memorandum aims to establish a system of supervision of standards proscribed by international conventions adopted within the framework of IMO and ILO which are already in application. During an inspection of a foreign ship, the competent inspectors verify

6. They are: Belgium, Bulgaria, Croatia, Cyprus, Denmark, Estonia, Finland, France, Germany, Greece, Island, Ireland, Italy, Canada, Latvia, Lithuania, Malta, the Netherlands, Norway, Poland, Portugal, Romania, Russia, Slovenia, Spain, Sweden, United Kingdom. 
whether the ship has valid documentation compliant with the provisions of international conventions.

All Memorandum signatories are required to maintain an efficient system of supervision of control of ships entering their ports to ensure that all ships, without exception, comply with the standards of the applicable international conventions.

During inspection, an inspector aims to determine whether a ship carries on board the required certificates, poses a threat for the safety, health or the marine environment, has security protection and whether the crew have the satisfactory level of knowledge required for the safe navigation of the ship. If a ship is found to be non-compliant with the proscribed standards, she will be forbidden to leave the port until made capable for continued navigation without danger to human life or the marine environment.

As of 1 January 2011, a new inspection regime entered into force at the level of Paris Memorandum member states, aiming to eliminate sub-standard ships by introducing stricter criteria for ships and companies failing to meet the requirements of international maritime conventions. One of such new measures introduced by the new inspection regime is the permanent expulsion of sub-standard ships from Paris Memorandum ports.

\subsection{National Legislation}

Finally, having described all contents, the process of ratification and implementation of international agreements and conventions into national legislation needs to be examined.

The ratification procedure in the Republic of Croatia is similar to the procedure used in the Croatian Parliament to adopt laws and regulations . Pursuant to the Constitution of the Republic of Croatia, as a country's most important piece of legislation, international agreements in force and effect, concluded, ratified in compliance with the Constitution and published, are a part of the internal legal system of the Republic of Croatia and are by their legal force above the law. Their provisions may be amended or cancelled only under the conditions and in the manner stipulated in such agreements or in keeping with the general rules of international law.

The Maritime Code was adopted and entered into force in December 2004, and amended in 2007, 2008, 2011, 2013 and 2015. The Croatian Maritime Law rests on the provisions of the 2004 Maritime Code. The Maritime Code is divided into twelve parts and 1032 articles. It regulates all major publiclegal and property rights relations relating to the sea, maritime navigation and seagoing vessels. A number of legal and sub-legal regulations dealing with certain elements of the subject matter in more detail were adopted on the basis of the Maritime Code.

With the adoption of the 2004 Maritime Code, the Croatian maritime legislation became compliant with the contemporary and generally established solutions of international unification instruments ratified by the Republic of Croatia. By adopting international maritime standards, the Republic of Croatia largely conformed its internal maritime legislation with contemporary, generally established solutions proscribed by international instruments and EU regulations from this area, and the Maritime Code is now considered one of the most modern maritime codes in the world.

\section{AMENDMENTS TO THE 2013 ORDINANCE ON VOCATIONS AND CERTIFICATES OF COMPETENCIES FOR SEAFARERS}

The new Ordinance on Vocations and Certificates of Competencies for Seafarers was adopted in $2013^{7}$ and amended in $2014^{8}$, thereby implementing the amendments to the 2010 STCW Convention into national legislation. The Ordinance is also compliant with the provisions of Directive 2008/106/EC on the minimum level of training of seafarers and provisions of Directive 2012/35/EC amending Directive 2008/106/EC on the minimum level of training of seafarers. The Ordinance of 2007 ceased to apply upon entry into force of the Ordinance of 2013.

Annex $C$ to the Ordinance proscribes exam programs and enumerates, under $\mathrm{C} 7$, the courses a trainee is required to pass to obtain the title of Chief Officer on vessels of 3000 BT or more and Master on vessels of 3000 BT or more, namely: Navigation and planning (oral and written); Cargo handling and ship stability (oral, written and practical); Ship maneuvering and avoiding collisions at sea (oral and practical); Safety at sea (oral and practical); Ship maintenance (oral); Meteorology with oceanography (oral); Maritime law (oral); English language (oral and written).

The maritime law exam is taken in compliance with the training program referred to in Annex A2 of the Ordinance activity: Controlling the operation of the ship and care for persons on board at the management level; Monitoring and controlling compliance with legislation and measures aiming to ensure the safety of life at sea and protect the marine environment - Knowledge of international maritime law contained in international agreements and conventions.

The Ordinance of 2007 was better at elaborating the subject matter of maritime law - although not well laid-out, it dealt with the overall subject matter in a more detailed manner. Annex A to the Ordinance of 2013 does not proscribe the minimum number of hours for any course content, including maritime law. The Ordinance should, apart from requirements set by international regulations, also contain national legislation required to be taught at a certain level of training.

Annex $B$ to the Ordinance proscribes a special training program, enumerating under item B1 courses of the special

7. Official Gazette no. $130 / 13$.

8. Official Gazette no. 54/14. 
training program a trainee is required to pass to earn the title of Chief Officer on vessels of 3000 BT or more, held at maritime faculties and departments. To enter the special training program, trainees are required to have a minimum of 36 months of seagoing service in the capacity of officers of navigational watch on vessels of 500 BT or more. 45 hours of lectures from maritime law are proscribed in the special training program for the obtainment of the title of Chief Officer on vessels of 3000 BT or more, held at faculties and departments of maritime studies. Since new Model Course 7.01 proscribes 54 hours of lessons from maritime law, the Ordinance needs to be correspondingly modified. Course content is compatible with new Model Course 7.01. In spite of the insufficient number of hours, special training program (Annex B) is elaborated better than the program used in the framework of regular classes at maritime faculties and departments (Annex A).

\section{CONCLUSIONS}

Although ship navigation during sailing has been significantly facilitated by the development of technics and technology, seafarers are now required to be well-versed in an increasing number of maritime law regulations and procedures promoting the safety of life and property at sea and the protection of the marine environment, while simultaneously ensuring unobstructed exploitation of ships. That especially goes for the Master, as the person with the highest responsibility on board a ship. The STCW Convention standardizes the training of seafarers at international level. The amendments of 2010 ensure better supervision of implementation of the STCW Convention and practice in certain states.

The Republic of Croatia is required to ensure consistent application of the provisions of the STCW Convention to raise the safety of navigation standard by establishing a working cooperation between competent state administration bodies and scientific and educational institutions. The latest amendments to the STCW Convention in this sense, in Model Course 7.01., impose additional seafarer training requirements, inter alia, broadening the scope of mandatory contents to be covered by maritime law programs required for the obtainment of professional title of ship officer. Furthermore, the total number of hours of maritime law courses was increased.

Since Model Course 7.01 is only concerned with the part of the program covering international maritime law, its content needs to be supplemented to include national regulations governing each individual institute. Other Maritime Code content unregulated by international legislation also needs to be covered, including the ship's legal status, marine and submarine areas of the Republic of Croatia, organization of the safety of navigation service in the Republic of Croatia and the legal status of maritime demesne and ports.

At the national level, there is a discernible lack of uniformity of national regulations intended to proscribe programs taught at maritime faculties and departments in more detail. Namely, the Ordinance on Vocations and Certificates of Competencies for Seafarers of 2013 is not fully compatible with new Model Course 7.01 in the area of seafarer training in maritime law. Syllabus needs to be elaborated in more detail, including by proscribing minimum hours for each subject matter taught, and in case of the special training program, by increasing the total hours of training in maritime law, as stipulated in Model Course 7.01.

\section{REFERENCES}

Baumgartner, D., (2011), Inspekcijski nadzor sigurnosti plovidbe i zaštite morskog okoliša u Republici Hrvatskoj, Master thesis, Split: University of Split, Faculty of Law.

Borčić, V., (1992), Pomorski agent, Rijeka: University of Rijeka, Faculty of Maritime Studies in Rijeka.

Degan, V.-Đ., (2000), Međunarodno pravo, Rijeka: University of Rijeka, Faculty of Law.

Grabovac, I. and Petrinović, R., (2006), Pomorsko pravo - pomorsko javno, upravno i radno pravo, Split: University of Split, Faculty of Mairitime Stuides in Split.

Ibler, V., (2001), Međunarodno pravo mora i Hrvatska, Zagreb: Barbat.

Jakaša, B., (1983), Udžbenik plovidbenog prava, Zagreb: Narodne novine.

Lušić, Z., (2014), Novi preddiplomski studij Pomorske nautike na Pomorskom fakultetu u Splitu, Kapetanov glasnik, 29, pp. 22-25.

Luttenberger, A., (2005), Pomorsko upravno pravo, Rijeka: University of Rijeka, Faculty of Maritime Studies in Rijeka.

Mandić, N., (2010), Ugovor o pomorskoj agenciji, Master thesis, Split: University of Split, Faculty of Law.

Milošević-Pujo, B. and Petrinović, R., (2008), Pomorsko pravo za jahte i brodice, Split: University of Split, Faculty of Maritime Studies in Split.

Pavić, D., (2006), Pomorsko imovinsko pravo, Split: Književni krug.

Petrinović, R. and Lovrić, I., (2015), Osiguranje pomoraca prema novoj Konvenciji o radu pomoraca, Poredbeno pomorsko pravo, 54(169), pp. 145-170.

Petrinović, R., Skorupan Wolff, V. and Mandić, N., (2013), LOF 2011 - New Revision of the Lloyd's Standard Form of Salvage Agreement, Proc. $5^{\text {th }}$ International Maritime Science Conference, Split, Croatia, April 22-23, pp. 254-261.

Petrinović, R. and Škiljo, M., (2010), Pravilnik o mjestima zakloništa - pruža li Pravilnik priželjkivanu zaštitu hrvatskog morskog okoliša?, Poredbeno pomorsko pravo, 49(164), pp. 309-343.

Pravilnik o upravljanju i nadzoru balastnih voda, (2012), Narodne novine, 128(2012).

Pravilnik o zvanjima i svjedodžbama o osposobljenosti pomoraca, (2013), Narodne novine, 130(2013).

Pravilnik o zvanjima i svjedodžbama o osposobljenosti pomoraca, (2014), Narodne novine, 54(2014).

Pravilnik o zvanjima i svjedodžbama o osposobljenosti pomoraca, (2015), Narodne novine, 124(2015).

Rudolf, D., (2012), Enciklopedijski rječnik Međunarodnog prava mora, Zagreb: Matica Hrvatska.

Seršić, M., (2003), Međunarodnopravna zaštita morskog okoliša, Zagreb: University of Zagreb, Faculty of Law.

Vidan, D., (2012), 2010 Manila izmjene STCW konvencije, Kapetanov glasnik, 24, pp. 16-20. 